\title{
The powers of problem definition: The case of government paperwork
}

\author{
JANET A. WEISS \\ Institute of Public Policy Studies, University of Michigan, Ann Arbor, MI 48109-1220, U.S.A.
}

\begin{abstract}
Problem definition is a package of ideas that includes, at least implicitly, an account of the causes and consequences of undesirable circumstances and a theory about how to improve them. As such, it serves as the overture to policymaking, as an integral part of the process of policymaking, and as a policy outcome. In each of these roles it seems to exert influence on government action. Distinguishing among the roles clarifies the nature of that influence. A case study examines the transition from one problem definition to another in the domain of information collection by the federal government. The rise of the Paperwork Reduction definition illustrates the variety of ways in which problem definition has powerful consequences.
\end{abstract}

Problem definition is widely regarded as the first stage of the policy cycle, a stage that lays fundamental groundwork for the ensuing struggle over the construction of useful policy alternatives, authoritative adoption of a policy choice, implementation, and assessment (Brewer and deLeon 1983). Definition in this sense is not merely a label for a set of facts and perceptions. It is a package of ideas that includes at least implicitly an account of the causes and consequences of some circumstances that are deemed undesirable, and a theory about how a problem may be alleviated (Dery 1984, Gusfield 1981). By the frame imposed on circumstances, a problem definition highlights some aspects of the situation, throwing other aspects into shadow. It pushes forward some potential solutions, neglecting others (Gamson and Modigliani 1987).

The definition of problems at the outset of the policy process may have various sources: the lonely analyst wrestling to impose intellectual structure on a messy array of facts and dilemmas; savvy politicians crafting issues to appeal to the winning mix of voter demographics; a crisis event splashed across the front page to galvanize attention to previously neglected corners of social life; the insistence of disenfranchised groups that their concerns be taken seriously by those more comfortably circumstanced. Whatever the precipitating factors, problem definition determines how people think about the problems that are (and are not) on the public agenda. ${ }^{2}$

I endorse the importance of the initial definition of the problem, as it has been typically considered in the policy literature. A problem definition at the outset of the policy process has implications for later stages: which kinds of 
evidence bear on the problem, which solutions are considered effective and feasible, who participates in the decision process, how policies are implemented, and by which criteria policies are assessed. But in this article, I argue that problem definition is more than the overture to the real action; it is often at the heart of the action itself.

As the policy process unfolds, problem definition may remain an open question. Although analysts prefer to settle on a given problem definition before proceeding with their work, the policy process does not require agreement on a problem definition before legislative or bureaucratic action ensues. As advocates seek to attract attention to new policy proposals, they may do so by proposing substitutes for the definitions guiding existing policies. As policymakers struggle through the process of authoritative decision making, they typically face not only multiple options for addressing a given problem, but multiple definitions each implying its own family of solutions. Multiple definitions may survive to haunt the implementation process, as differing conceptions of the problem guide the various actors who work to turn the official rhetoric into many realities (Katzmann, 1986). A common language of problem definition can be stitched together to permit coalitions to move forward one policy or another for a time (Edelman, 1988). Later, consensus unravels as circumstances change, competing definitions gain adherents, and new coalitions form.

Problem definition cannot be definitively settled and locked in at the beginning. Sometimes problem definitions persist from start to finish, from year to year, even from generation to generation. But other times analysts, advocates, and policy makers continue to argue over problem definition as problems are introduced, evidence considered, solutions debated, decisions made, programs implemented, and policies evaluated. At whatever stage a new problem definition gains significant support, it shapes the ensuing action. It legitimates some solutions rather than others, invites participation by some political actors and devalues the involvement of others, focuses attention on some indicators of success and consigns others to the scrapheap of the irrelevant. To reap these rewards, participants in the policy process seek to impose their preferred definitions on problems throughout the policy process. Much policymaking, in fact, is preoccupied with whose definitions shall prevail.

To illustrate these claims and their implications, I analyze the conflict over problem definition in one policy domain, the case of federal paperwork. The policy problem is quite simple. On one hand, federal officials who devise and operate complex policies to benefit a large, heterogeneous population have to know a great deal about the needs of the population and its responses to federal action. To find out, they collect information in standardized, written format from many sources at frequent intervals. Without such knowledge, 
neither sensible federal programs nor democratic accountability would be possible (Weiss \& Gruber, 1984). On the other hand, Americans are suspicious of big government (Huntington, 1981). They resent the intrusion of public officials into private realms of action. They begrudge the costs of providing detailed accounts of their activities to serve bureaucratic purposes. The clash of these two powerful pressures, one for more information and one for less, means that something has to give.

Although the facts are straightforward, the problem definition is not. The tension between the need to know and the costs of finding out has been reconciled in two different ways over the last fifty years. During the period between the 1930's and 1974, the dominant problem definition gave primacy to the government's need for information. I call it the Government Intelligence definition. It highlighted the need for information to guide government action and to permit oversight by elected officials. It relegated the burdens of collection to the status of regrettable but minor inconveniences. After 1974 a second definition of the problem came to the fore. I call it the Paperwork Reduction definition. It directed attention to the significant burdens of paperwork on the public and the economy, and pooh-poohed the claims of government officials to need so much information. Something had to give. But what has given has depended on which definition of the problem was in vogue at the time.

By looking at the transition from the Government Intelligence definition to the Paperwork Reduction definition, this paper considers the variety of ways in which problem definition exerts power in the policy process. It shows how policy actors struggle over problem definition throughout the policy process, how political context shapes problem definition, and how consensus on problem definition influences successive rounds of policymaking. The triumph of the Paperwork Reduction definition was a policy outcome of considerable significance, as important perhaps as the administrative and policy changes that it inspired and justified. By tracking the process and consequences of problem definition in this one policy process, the case suggests the complex roles of problem definition - as the intellectual framework that sets the context for policy deliberation, as the focus of political debate and advocacy in legislative and bureaucratic decision making, and as one of the ultimate products of policy action.

\section{The Government Intelligence definition}

Before the New Deal, there was little conflict between the need for information and the resistance to collecting it. The federal government simply did not collect much. But the New Deal legislation of 1933 dramatically increased 
the need for data, and unleashed a wave of forms and surveys upon the land. Complaints from disgruntled respondents immediately followed. President Roosevelt and a newly-created Central Statistical Board attempted to respond to the complaints by eliminating cases in which several agencies requested the same information from the same sources (Commission on Federal Paperwork 1977a, Feldman 1970). The complaints subsided through the 1930 's, only to surge again when the onset of World War II triggered massive new data collection. The allocation of materials, selective service, production controls, and price controls all required substantial new information, which in turn required new data collection. This time the Congress stepped in to address the issue.

The Federal Reports Act of 1942 (PL 77-831) established for the first time legal guidelines to permit the collection of necessary information and reduce the burdens of paperwork on the public. It permitted federal agencies to collect information that agency officials deemed necessary for the proper performance of agency business. It gave the Bureau of the Budget authority to review and clear all agency plans to collect information, except those from the Treasury Department (notably the Internal Revenue Service) and the bank regulatory agencies. Clearance was to be denied if some other agency was already collecting the same data or if the information request was patently improper (Office of Statistical Standards 1952).

The definition of the problem implicit in the Federal Reports Act had several parts. First, federal officials appropriately decided what they needed to know. Second, citizen complaints about paperwork stemmed largely from the failure of citizens to appreciate the government's need for information to meet complex legal and political pressures. Third, unreasonable burden existed when two agencies asked the same firms or households for the same information. The dominant causal theory blamed unreasonable burden on fragmentation and lack of coordination among federal agencies. Thus the solution for unreasonable burden was to prevent two agencies from asking for the same information by coordinating requests from a central location.

This set of ideas, which I call the Government Intelligence definition, was linked by its supporters to a handful of cultural symbols and values that bolstered its arguments. The importance of rationality and expertise in government decision making was the most obvious. But this definition also stood for due process, the protection of citizens against arbitrary or biased actions of government agencies that were not guided by systematic information. By blaming people for complaining about their obligations to provide information to the government, it emphasized the legitimacy of government claims on information about society. Its resonance with widely accepted values strengthened its claim to political acceptance among the policy makers and senior bureaucrats who were most directly involved. It placed protesters 
at a disadvantage by casting their objections as illegitimate (Kaufman 1977).

Although the Government Intelligence definition failed to make paperwork popular, it protected information collection for many years. Between the middle thirties and the middle seventies, the Bureau of the Budget continued to approve nearly all requests for clearance of information collection. From time to time, congressional committees or other elected officials indignantly pointed to the jungle of paperwork perpetrated by the federal bureaucracy. ${ }^{3}$ But these bursts of ire were short lived. During the entire period, no efforts were made to change the Federal Reports Act procedure in any major way, nor were serious proposals put forward to address the burdens of information collection (Neustadt 1981). The consensus on the Government Intelligence definition held through the spurts in data collection that accompanied price controls during the Korean War, the wage and price guide posts of the Kennedy-Johnson era, and the 1971-73 freeze on prices followed by price controls. It held through Democratic and Republican administration, through periods of expansion and quiescence in government activity. But after 1974 it came undone.

\section{The Paperwork Reduction definition}

A new definition of the problem superseded the old by reinterpreting the tension between the benefits of having information and the costs of collecting it. Where Government Intelligence permitted federal officials to decide what they needed to know, the Paperwork Reduction definition assumed that federal bureaucrats left to their own devices would ask for too much. Congress, with its more refined political sensibilities, had a better capacity to balance legitimate needs for information against the burdens on citizens. This definition interpreted complaints about paperwork as legitimate concerns of aggrieved citizens, not as a failure of citizens to fulfill legitimate obligations. 'Unreasonable burden' existed whenever agencies sought to collect information beyond that required by the Congress. The causal theory blamed unreasonable burden on uncontrolled bureaucratic imperialism and the perverse incentives that allowed bureaucrats to enjoy the benefits of information while shifting the costs to respondents. The solution for burden was to adjust the incentive structure, to require agencies to pay a higher 'price' for information they wished to collect by creating demanding standards for clearance and a cap on total burden that each agency was permitted to impose (OMB 1979, 1981).

The Paperwork Reduction definition was translated into action through a series of administrative reforms and executive orders between 1975 and 1979. With the support and prodding of the Congress, Presidents Ford and 
Carter pursued it enthusiastically. During this period, the Office of Management and Budget pursued a Forms Reduction Program to cut the number of federal reports, changed its criteria for approving information collection by the agencies, began a Burden Reduction Program to reduce the number of hours spent completing federal forms, created an Information Collection Budget to limit information requests from the agencies to a fixed annual number, ordered sunset provisions on all reports so that each form would have to be reviewed at regular intervals, and required agencies to restrict data collection from small enterprises. In 1980 these initiatives were ratified in the Paperwork Reduction Act of 1980, which repealed the Federal Reports Act of 1942 and substituted the language and ideas of the new problem definition.

Like its predecessor, the Paperwork Reduction definition evoked a set of cultural symbols and values. Its advocates discussed data collection in terms of intrusion of government into private matters of family and business, suspicion of centralized authority, skepticism about the competence and good will of federal bureaucrats, and the importance of individual freedom from surveillance. As these values were woven into arguments about policy toward information, they lent emotional punch to the logic of paperwork Reduction.

\section{The transition from Government Intelligence to Paperwork Reduction}

Problem definition in public policy is both important and elusive because it is embedded in such complex structures for decision and implementation. The ideas carried by Government Intelligence and Paperwork Reduction became influential because they took hold in several loosely connected communities of elites: political appointees in agencies (notably OMB and the General Accounting Office (GAO)) with a government-wide orientation, Congressional staff of committees responsible for government operations, lobbyists for business and state and local governments, and elected officials in Congress and the White House. The domestic policy arena is composed of many of these communities, each with its own perspectives and interests. But all need at least some of the others to flourish. To understand problem definition as a political process, an analyst must track how ideas about public policy travel across communities and institutions of policy making.

Two harbingers of the transition in problem definition appeared in 1974. Shortly after assuming the Presidency in August, Gerald Ford placed regulatory reform high on his policy agenda (Ford 1979). Over time, he included paperwork reduction as a feature of desirable deregulation. In December, Congress created a Commission on Federal Paperwork (PL 93-556) to consider ways to measure and minimize the paperwork burden on non- 
federal respondents. From these modest beginnings, the Paperwork Reduction definition infiltrated the policy process. It resulted in significant changes in official policy and bureaucratic practice that could not have occurred under the old definition. However there was nothing inevitable about the change in problem definition. Nothing in this analysis suggests that the forces culminating in problem redefinition were unstoppable. This discussion points out the process that made redefinition more likely, not the mechanisms that escorted paperwork reduction to its place in destiny.

President Ford's policy agenda during his years in office was dominated by inflation, recession, and the aftermath of OPEC's oil embargo. Like most presidents, he had little time for discretionary issues (Light 1982). But he made one issue distinctly his own - regulatory reform. In October 1974 he addressed a joint session of Congress on the subject. Throughout 1975 and 1976 regulatory reform was a frequent topic of Ford's speeches and legislative initiatives. To Ford's chagrin, many of these initiatives were stymied in Congress and in the independent regulatory agencies. But paperwork proved to be a vehicle for regulatory reform over which the White House had considerable control. In speeches and public meetings, he repeatedly linked paperwork to regulatory relief. In July 1975, he told the Commission on Federal Paperwork:

Freedom will depend in part on our ability to preserve individuality and to avoid a government so large and bureaucratic that it stifles initiative. That is one reason I have taken a personal interest in the problems associated with the collection of information by government... The more than 5000 different forms which individual citizens are forced to fill out generates more than two billion pieces of paperwork each year. And that's too much... (Ford 1975a).

In a speech to small business owners, he declared:

I want an end to unnecessary, unfair, and unclear regulations and to needless paperwork. The number of different federal forms sent out by Washington at last count totalled 5146. America is being buried in an avalanche of paperwork (Ford 1975b).

To the US Chamber of Commerce, he explained his support for the Commission on Federal Paperwork:

I intend to see that its very wide powers are used effectively to cut down the unnecessary burden on our American free enterprise system (Ford 1975 c). 
Although Ford's economic advisors were focused on pro-competitive deregulation, Ford himself kept coming back to paperwork. In an unprecedented White House meeting with the heads of the independent regulatory agencies, he asked them to reduce by $10 \%$ the number of forms that they used (White House Press Office 1976). His speeches, especially those to business audiences, referred to the 'nightmare,' the 'increasing tide,' the 'red tape jungle,' the 'paperwork mountain,' the 'growing suffocation,' and the 'avalanche of paper.' A series of public forums organized by the White House in the fall of 1975 elicited a slew of well-publicized complaints about government red tape (Domestic Council 1975). In March 1976 Ford ordered the executive agencies to cut by $10 \%$ the number of forms they used before June 30 (Ford 1976a). When they did so (often by stapling several short forms together to make one longer report), he asked them to cut the amount of time required to fill out the forms by 7 million hours (Oaxaca 1976). In September 1976 , he asked for an additional reduction of 20 million hours of burden (Ford 1976b). His Director of the Office of Management and Budget revised the criteria for clearance of agency requests to collect information (OMB 1976). Now the information to be collected had to be necessary for the proper performance of the agency's function, not available elsewhere, and have 'practical utility.' This meant the agency had to show how it could and would use the information once it had it.

Ford was the most prominent, but not the only advocate of Paperwork Reduction. Also active during 1975-76 was a small group of Congressmen and Senators who adopted paperwork as one of their issues ${ }^{4}$ Before the Ford administration, Government Intelligence was firmly entrenched in Congress. Although conservatives fulminated on the sins of bureaucrats, only the small business committees ever used the language of paperwork reduction, and they had no jurisdiction. The House Committee on Post Office and Civil Service, no hotbed of liberal activism, released biennial reports on the 'Statistical Activities of the Federal Government.' The 1971 report read:

With each succeeding year, there is growing recognition of the need for better statistical information on which to base decisions required to conduct modern government and business activities. The increasing magnitudes and complexities of present-day government and society in general appear to require more accurate and pertinent data, which is dramatically represented in the total statistical expenditures of over $\$ 491$ million... (Committee on Post Office and Civil Service 1971).

During the midseventies, however, paperwork reduction became increasingly popular, most importantly in the House and Senate committees on Government Operations. After 1974, hearings emphasizing the burdens of paper- 
work were held every year in both Houses. Individual members began to introduce bills that borrowed language from Ford's speeches. One bill proposed that, if OMB could not exercise firm control over the agencies, then GAO should do the clearance (S 1812). Another proposed that each Congressional committee review and prune all reporting requirements of agencies within its jurisdiction (S 3076). A third proposed an income tax credit for each respondent who completed a federal form of 10,20 , or 30 cents for each item of information (HR 11983). Individual Senators and Representatives sought to reduce information collection in particular policy areas: hearings on 'Paperwork requirements of the Pension Reform Act' or a bill on Customs Paperwork Reduction Act. Others addressed the issue across the government: Government Forms Justification Amendments (S 2443, 1975), Form Reform Act (S 2132, 1975), Efforts to Reduce Federal Paperwork (Hearings 1975), Paperwork Review and Limitation Act of 1976 (S 3076), and so on. Although Congress did not act in any authoritative way at this stage, the ideas of Paperwork Reduction were clearly receiving serious attention.

Meanwhile the Commission on Federal Paperwork that had been established in 1974 was proving to be another source of effective advocacy. Althoug it was a conventional study commission, with no particular authority or resources, it proved strikingly successful at promoting Paperwork Reduction within the Congress. The Commission was composed of four members of Congress, the Comptroller General, and representatives from state and local government, business and consumer groups.

The Commission took several steps to elaborate and legitimize the emerging paperwork reduction definition. First the staff worked hard to develop quantitative indicators of paperwork burden. The indicator used by the Federal Reports Act (i.e. the number of reports) was not sufficiently exciting. The Commission worked up several alternatives; the number of sheets of paper and the height of a stack of government forms were two early efforts (Commission on Federal Paperwork 1976). But in the end they came up with a politically compelling number. The final report concluded that 'more than $\$ 100$ billion a year, or about $\$ 500$ for each person in the country, is spent on federal paperwork... A substantial portion of this cost is unnecessary.' (Commission on Federal Paperwork 1977b.) Even if no one had a clue what all that paperwork was, or what portion was unnecessary, $\$ 100$ billion was self-evidently too much. The number was frequently invoked as the Administration and Congress worked on the problem.

The Commission also published 36 reports and a raft of position papers that made 770 detailed recommendations to the executive branch and the Congress about steps to reduce unnecessary paperwork. Although some of these were quite general (for example, that Congress should exercise more 
oversight over information collection by agencies), many were detailed (for example that OMB should accept a single annual certification by a Mayor as evidence of local compliance with federal policies that are conditions of federal grants). The Commission held public hearings in 19 cities. It set up a Paperwork Hot Line that received 3500 complaints. Commissioners and Commission staff testified repeatedly (and successfully) before Congress to encourage adoption of their recommendations. For example, a proposal to cut back filling of IRS Form 941 from quarterly to annually passed both Houses in December 1975. Over the protests of the Department of Labor, which pointed out that state governments relied on these reports, President Ford signed the bill. The Commission articulated pragmatic strategies that transformed paperwork reduction from a political slogan into feasible and respectable proposals with a patina of expertise.

By the time the Commission published its reports, Jimmy Carter was sitting in the White House. Having campaigned against big government, he consolidated the shift that Ford had begun. At his first cabinet meeting, he asked his senior appointees to cut red tape. He followed up with a memo asking each cabinet member to get 'personally involved' in reducing paperwork (Carter 1977). His OMB reissued the guidelines that Ford's OMB had circulated five months earlier asking for a reduction of 7 million hours of paperwork burden (Lance 1977). When the Commission on Federal Paperwork released its findings, OMB was under strict instructions to implement the recommendations. Carter asked for progress reports every six months on how many recommendations had been followed (OMB 1978).

In 1979 White House staff convened a working group of Congressional staff and OMB officials to draft Executive Order 12174 to strengthen OMB's powers to restrict the collection of information by federal agencies (Neustadt 1981). The Executive Order called for an annual budget that would give each agency a fixed number of burden-hours to 'spend' each year to collect the information it needed. It tightened up the official criteria for clearance by requiring agencies to show exactly how they intended to use the data they requested. Additional provisions made clearance criteria more stringent for data collection from small business and for recurring reports. Although President Carter enthusiastically signed the executive order in November, he also pushed for legislative changes. The Congressional supporters of Paperwork Reduction were eager to cooperate. Those Representatives and Senators who had served on the Commission on Federal Paperwork joined forces with members of the Government Operations committees. By 1980 the Paperwork Reduction Act moved swiftly through committee to the floor. It passed overwhelmingly in December. Five cabinet secretaries pleaded with Carter not to sign it on the grounds that it would make their jobs harder. In 
his signing statement, Carter exulted 'we've addressed the bureaucrats and we've won' (Neustadt 1981).

The Paperwork Reduction Act repealed the Federal Reports Act, and institutionalized the Paperwork Reduction definition. It set into law many of the provisions of Executive Order 12174. It brought all agencies of the federal government under its scope, ending the exemptions of the IRS and the regulatory agencies. It instructed OMB to reduce by $25 \%$ the hours of burden caused by paperwork. The problem redefinition was complete. When Ronald Reagan took office a month later, the conceptual, legal and administrative apparatus was in place 'to cut away most of the underbrush of paperwork burden.' (OMB 1985).

The promoters of Paperwork Reduction had framed their case in a way that discouraged opposition. The senior bureaucrats who were direct beneficiaries of Government Intelligence immediately conceded the legitimacy of paperwork reduction concerns, and focused their energies on protecting themselves from its implications. Many bureaucrats argued that burden reduction was, of course, desirable, but the information they collected was necessary. For example, the head of the Energy Research and Development Administration testified in 1976:

The Paperwork Review and Limitation Act would impose the laudable goal of reducing the number and complexity of forms used by the federal government in compiling data... However imposition of these stringent procedural road-blocks to information acquisition could severely hinder achievement of our goals. (Committee on Government Operations 1976.)

And the Central Intelligence Agency sang the same tune in 1979:

The Intelligence Community fully supports these legislative objectives [of paperwork reduction]. However the bills contain several provisions which would impact adversely on the Intelligence Community in the conduct of its foreign intelligence and foreign counterintelligence missions. (Senate Report 96-930, 1980).

Speaking for the statistical community in 1975 , the chief statistician in the federal government wrote:

Information is needed; to get information, questions must be asked; to answer questions is a burden and that is the circle of the present paperwork predicament. While we all complain bitterly about government paperwork, we also complain about lack of information when critical 
decisions are to be made. We still recall, for example, the intense criticism of the government's lack of information about energy ... during the oil embargo. (Duncan 1975).

These arguments tried to incorporate burden into Government Intelligence without surrendering entirely to the new definition. They failed. Suggestions that the problem had two sides were easily overwhelmed by one-sided language about the 'growing suffocation' of the economy by 'mountains' of paperwork. Hence the advocates of Paperwork Reduction found few ardent defenders of the old definition in their path. Although Government Intelligence had been widely embraced and long established in public policy, its support turned out to be an inch deep.

Together a handful of players - Ford, Carter, several Congressmen and Senators, and the Commission on Federal Paperwork - redefined the paperwork problem for the entire federal government in a few short years. The features of the problem that they highlighted were not new; they had been lying around for years with scant political impact. The entrepreneurs focused attention on the costs of collecting information, directing attention away from the benefits. They advanced a new causal theory that blamed burden on bureaucrats rather than citizens. And they connected information policy to a different set of cultural values and symbols. By dramatizing this package of ideas, they spread the Paperwork Reduction definition through the communities of policymakers who used and collected government information.

\section{Connections between political context and problem definition}

Why was this problem redefined in the mid-seventies rather than earlier, later, or not at all? Which features of institutional, political, or social context made this problem definition appealing across institutional boundaries? This section considers three influences on this process: the objective features of the problem; the emergence of policy entrepreneurs; and fluctuations in the appeal of political symbols and language.

Changes in the problem. The advocates of policies to reduce paperwork often justified their proposals by the 'growing suffocation of federal paperwork' (Ford 1976). Obviously sudden or unprecedented increases in the burdens of information collection might account, at least in part, for sudden increases in enthusiasm for reducing the burdens. In spite of the rhetoric, there is little evidence that the burdens of paperwork were growing.

The only indicator of burden that was measured routinely and systematically between 1942 and the mid-70's was the number of reports approved by 
the Bureau of the Budget (later the Office of Management and Budget) under the Federal Reports Act procedure. OMB documents show that the number remained remarkably stable at about 5000 reports a year during this 35 year period. Peaks in 1944, 1952, 1963, and 1973 were due to the imposition of economic controls. In each case, large drops followed the removal of the controls. The $1944-45$ drop was 6300 to 5000 ; in $1952-53$ it was 5900 to 4800 ; in $1963-64$ it was 5200 to 4600 ; in $1973-74$ it was 5700 to 5000 . (OMB 1978).

A better measure than number of reports is number of hours required to complete the reports (Commission on Federal Paperwork 1977c). OMB began to keep track of reporting hours beginning in 1968. The 110 million hours devoted to federal reports in 1968 increased to 130 million in 1971 and to 168 million in 1973 . However by 1974 the total had dropped back to 122 million hours, paralleling the drop in number of reports (OMB 1978).

Thus the embrace of a new problem definition in the 1974-76 period was not obviously triggered by a sudden or unprecedented increase in measurable burden. Although it is conceivable that the agencies exempted from the Federal Reports Act had dramatically stepped up their collection of information, no systematic evidence of this entered into Congressional deliberations. The available measures showed that burden was approximately what it had been for the entire postwar period. The increases in the early seventies were no sharper than those of the early fifties or sixties, and the trend had already turned markedly downward when the President and Congress took up the problem. Nor did any crisis event bring paperwork reduction to the fore. If information collection was a problem in 1974, it had probably been a problem of about the same magnitude for many years.

Policy entrepreneurs. Problems often come to seem important because of the activities of sponsors who promote favored solutions to problems in part by emphasizing the importance of the problems themselves (Kingdon 1984). These advocates impress on policymakers the need for action to pave the path to acceptance of the policy or program to address the need. In classic fashion. the policy entrepreneurs in this case promoted paperwork reduction policies by stressing the damage wrought by information collection.

Ford, Carter, and the other policy entrepreneurs were not the first to advocate the Paperwork Reduction view. Others had attacked federal paperwork over the years. but in the past these attacks had been scattered and ineffectual. After all, the issue is not intrinsically glamorous or exciting. The arcane operations of the bureaucracy stir little interest beyond the Beltway. The issue did not turn out the vote of broad-based interest groups. The predecessors to the paperwork entrepeneurs of the 1970's had been unable to attract the attention of issue-oriented communities of policy makers in Con- 
gress and the executive agencies. The entrepreneurs of the 70's succeeded. Part of the success lay in the personal involvement of the President of the U.S. and part lay in the new receptivity of the audiences. The political climate had changed, making it easier for the new set of policy entrepreneurs to be heard.

Political context and political symbols. When many ideas compete for the attention of policy makers, the winners are determined not only by the relative merit of the ideas, but also by the preoccupations of the policy makers. These preoccupations are determined partly by the events of the moment, and partly by the institutional structure in which policy makers live. Both events and institutional structure in the mid-seventies created preoccupations that were receptive to the arguments in the Paperwork Reduction definition of the problem.

The years 1974 to 1976 marked a tumultuous period in American politics. The end of the Vietnam war and the Watergate scandals highlighted the public's loss of confidence in the institutions of national government. The inflation-recession roller-coaster eroded confidence in economic policy. Disillusion with social programs crept into political debate. Among policy makers and among citizens, enthusiasm for big government began to wear thin.

Public opinion, however, seldom translates neatly into crisp official response. Elected officials have to interpret the public mood to mean that some symbols and principles are important to voters and others are not. Because the evidence about public preferences on matters of policy is nearly always ambiguous, politicians tend to look at the deep structure of public opinion, the handful of themes and ideas that seem to matter to people at the moment (Bennett et al. 1976). This handful of currently prominent themes is drawn from the inventory of themes and symbols acceptable in the mainstream political culture. The diversity and internal tensions within the inventory allow for a variety of 'national moods' to be created from the relatively modest pool of symbols (Elder and Cobb 1983). For example, norms of individual freedom may conflict with norms about the individual's obligations to the collective good, but both themes remain part of the cultural repertoire. As the society moves through periods in which one is dominant, the less popular idea disappears only from the current debate, not from the culture altogether. Eventually, the focus of attention shifts (Downs 1972). This complexity and cyclicity present frequent openings for defining and redefining problems.

During the middle seventies, politicians and pundits understood the drop in public confidence in government to mean that some values had fallen from favor while others were on the rise. Of interest for information policy, the 
value of rationality and due process in government decision making seemed to be badly shaken by the public's view of widespread incompetence and corruption in Washington. This view raised the salience of other symbols, especially individual freedom from government intrusion and fear of centralized authority (Cohen 1976). Whether this was an accurate reading of the public mind is beside the point. Politicians across party and ideological lines believed that citizens now, more than before, wanted to limit government intervention and wanted to restrict the discretion of government officials (Sundquist 1976).

Political events in Washington during the early seventies reinforced the politicians' suspicion of the federal bureaucracy. During the Nixon years, Congress grew mistrustful of undue politicization among senior agency officials. Ford and his successors distrusted bureaucrats who disregarded direction from the White House. Carter came to office on anti-government platform. Thus many politicians shared the public mood out of direct and concrete experiences in their own work.

Nearly all policy issues, even the narrow and technical, become framed in symbolic terms as they work through the political process, and must be contested in those terms (Gamson and Modigliani 1987). Skillful advocates hook their preferred policies to symbols that are powerful and resonate with the largest possible audience (Edelman 1988). They back off from those that have apparently become unpopular. Paperwork Reduction was easy to justify with the newly ascendant symbols of disenchantment and government restraint. In comparison, Government Intelligence, with its ties to rationality, lost symbolic punch. As a result the proponents of the Paperwork Reduction definition found that their message penetrated as never before. Policy entrepreneurs then set to work to translate this 'new' issue into concrete legislative and administrative proposals. These proposals escalated toward stricter and more complex controls as officials competed to promote appealing symbols.

The Paperwork Reduction definition became broadly acceptable in part because the receptivity to its arguments became remarkably broad. Because domestic policymaking is fragmented, 'semi-autonomous institutions develop their own norms and styles of interpretation of policy issues (Heymann 1987). This tends to make consensus on problem definition difficult to accomplish. For one idea to triumph over its competitors, it must take hold among groups that vary considerably in the respect they accord to any particular argument. In this sense, structural fragmentation militates against consensus. But even modest interdependence creates channels for shared interpretations of reality. When one committee in Congress sees things one way while another committee sees them differently, each must reckon with the other's judgments in order to emerge with collective decisions. When policymakers in legislative and executive branches have shared experiences 
over a long period of time and expect to work together in the future, these common experiences and expectations also contribute to the emergence of shared interpretations. ${ }^{5}$ In this case policymakers in Congress, the White House, OMB and GAO came to share a skepticism about federal bureaucrats, a protective stance toward individual privacy, a loss of faith in the efficacy of federal intervention that paved the way to wide acceptance of the Paperwork Reduction definition.

In the climate of the time, each group's interests could be advanced through the Paperwork Reduction definition. The President and the White House could use paperwork reduction as movement toward reform of excessive regulation, as a gesture of support for small business (an important constituency for Ford and Carter), and as a vehicle for control over the executive agencies. $\mathrm{OMB}$ and $\mathrm{GAO}$ officials, who serve as intermediaries between elected officials and the bureaucracy, had special insight into the excesses of the bureaucracy. They welcomed additional leverage to curb what they saw as defensive and imperialistic tendencies of agency officials (Committee on Government Operations 1980). The staff of the Government Operations committees in the House and Senate were eager to pursue an issue that promised visibility in the media and in the rest of the Congress. The Senators and Representatives who promoted Paperwork Reduction used their expertise and advocacy to raise their standing with the White House and with the business and education interest groups who supported the concept. For the Republicans, paperwork was also a device to restrict the expansionist tendencies of the executive agencies. For the Democrats, paperwork was a place to stand against the excesses of big government without opposing domestic programs. For all the groups, a further appeal of Paperwork Reduction was its bipartisan support. Policy proposals that do not automatically trigger partisan wrangling are rewarding because they are more likely to be adopted. Policymakers thus get a fix of real influence.

The shift in political context alone could not have led to the change in problem definition without the advocacy of policy entrepreneurs. Entrepreneurship appears to be a necessary (though not sufficient) condition for redefinition. But the activities of the advocates must be sensitive to multiple institutional realities and adapted to the fluctuating currency of political symbols to have much hope of success.

\section{Problem definition as the overture to policymaking}

In the lore of policy analysis, problem definition rightfully assumes great importance. Analysts tend to agree that artful definitions of policy problems are essential to the production of useful advice and the development of 
feasible solutions. After the analysts have moved on to new analyses, the problem definition may or may not take hold among policy makers. If it does take hold, it may or may not lead to changes in decisions, institutions, or behavior. In this tradition, problem definition is the beginning of a process with many possible ramifications.

If the redefinition of the information/paperwork problem was the first stage of policy making, what happened next? The change in definition from Government Intelligence to Paperwork Reduction made it possible for the information policies of the federal government to change in ways that earlier would have seemed odd and off the point. The American people have realized up to 300 million hours of paperwork burden reductions (OMB 1985, GAO 1984). As the Federal Reports Act gave way to the Paperwork Reduction Act, federal agencies lost considerable control over their access to information (Caudle 1988). What they lost, OMB gained. In the hands of a powerful and politicized OMB, this control has offered considerable leverage over the activities of the federal government in a variety of domestic arenas (Hopkins 1986). Such changes in policy, program, and administrative procedure took four to seven years to catch up with the preceding change in problem definition, in the face of weak to nonexistent opposition. Obviously, problem definition does not lead directly or automatically to subsequent policy. Given political institutions designed to check and balance, policy making and implementation in this case responded sluggishly and erratically to new ways of of understanding policy problems. But respond they did.

\section{Problem definition in the process of policymaking}

In this case, I have examined the interplay between defining problems and acting on them. This is a dynamic process in which intellectual understanding and institutional behavior guide one another over time. Unlike the one-way picture in which problem definitions sets the political process in motion and then fades from view, this perspective highlights the on-going power of problem definition.

For a new problem definition to take hold, it has to flow through the major arteries of the policy making arena. These arteries are not always easy to find or to penetrate. Although some policy sub-systems or issue networks are highly developed with well-known membership and regular interaction (Heclo 1978, Sabatier 1988), others are not. Those who construct and promote problem definitions benefit from creativity about the potential membership of such subsystems. In the case of government paperwork, as for many domestic issues, the policy arena consisted of a set of fragmented, diverse communities that did not routinely act in concert. Each community 
of policy makers and experts brought its own perspectives, incentives, and interests to bear on the question of when and how to collect information. Each had historical commitments to certain ways of thinking about information and routines for obtaining information. Each was organized around its own expectations about when and how information would be collected.

The advocates of a new problem definition needed to span institutional arenas - here, the senior civil servants, the pertinent Congressional committees, business interest groups, OMB and GAO. Only advocates who could find common ground across these diverse interests stood any chance to move forward their preferred definition. The discovery of common ground required some historical perspective on the positions adopted by various players and the values that those players might be willing to endorse, and an astute assesment of how opposing points of view would be defended. In a sense the advocates were engaged in the creation of a new issue network organized around the new definiticn. They promoted their problem definition by skillfully nurturing a supportive coalition, and were able to build their coalition because they had articulated a definition that organized the thinking and values of a diverse set of potential allies at that political moment.

Once they had succeeded in several of these communities, the advocates discovered that problem definitions may accumulate momentum. Small wins in a few places, such as the White House and the Government Operations committees, created pressure on contiguous communities, such as OMB and $\mathrm{GAO}$, to fall into line. The patient accretion of consent to an overarching definition lays the groundwork for victories at later stages of policymaking and implementation.

Problem definitions must accommodate political realities, but they also help to create those realities. Although the pressures of institutional interests restrict the range of definitions that receive serious consideration, problem definitions carve new channels in institutional arrangements. For example, OMB's earlier deference (in information matters) to the greater expertise in the agencies was replaced by its vigorous attacks on agency practice. Derthick's (1979) superb discussion of the definition of social security policy as a series of technical questions about social insurance provides another illustration of how problem definition redistributes power among participants in the policy process.

\section{Problem definition as the outcome of policymaking}

Finally, this case illustrates the importance of problem definition as a policy outcome in its own right. Problem definition creates language for talking 
about problems and non-problems that draws attention to some features of social life at the expense of others, locates responsibility for problems, putting some groups on the defensive and others on the offensive, widens and deepens public or elite interest in particular social phenomena, and mobilizes political participation around issues or symbols highlighted by the problem definition.

Language. The Paperwork Reduction definition changed the language used to talk about the information practices of federal agencies. All standardized questions are now officially called 'paperwork'. This includes tax forms, census questions, surveys, applications for benefits, monitoring and evaluation reports, record keeping requirements, grant proposals, loan and insurance applications, etc. When firms, households, state or local governments or nonprofit organizations respond to federal requests for information, they incur 'burden,' even when they initiate the interaction by applying for benefits or requesting assistance. The clear message of such language erodes the legitimacy of the request for information and signals that citizens appropriately feel aggrieved by the request. The words even derogate the government action that triggers burdensome requests for information. These seemingly minor changes in language and procedure work subtly and pervasively to undermine the bonds of obligation between citizens and the state. ${ }^{6}$ Although paperwork is not the only vehicle for examining the relationship between government officials and citizens, it is a potent one. Through the Internal Revenue Service and Social Security Administration alone, federal paperwork touches the lives of the vast majority of citizens. Just by changing the officially sanctioned language from Government Intelligence to Paperwork Reduction, the new problem definition created a subtle yet significant difference in the aspects of government activity that attracted public attention, applause, and opprobrium.

Responsibility. The Paperwork Reduction definition changed the allocation of blame and credit for the costs and benefits of data collection by federal agencies. Under the Government Intelligence definition, information was a good thing for government to have; hence information collection by bureaucrats (with a few exceptions) was good. Those groups who complained about the burdens of information collection were put on the defensive, and had to surmount the presumption that the burdens were not weighty enough to overcome the natural benefits of intelligence. Under the Paperwork Reduction definition, the tables were turned. The bureaucrats now had to surmount the presumption that they should not burden citizens. Respondents who complained about burden were now assumed to be right.

The shift in responsibility is obvious in the growing defensiveness of the 
executive agencies throughout the 1970's. In their testimony before Congress, senior agency officials repeatedly argued that their agency had particularly important needs for information that justified the burdens they imposed. Many agencies opposed the passage of the Paperwork Reduction Act of 1980 in spite of the President's support. The shift is also obvious in the growing activism of interest groups opposed to paperwork. The new problem definition gave considerable ammunition to groups such as the National Federation of Independent Business, Chamber of Commerce, Business Advisory Council on Federal Reports, Council of Chief State School Officers, and the newly organized Citizen's Committee on Paperwork Reduction. The ammunition was put to good use as these groups mobilized their members to oppose specific federal reports and to support tighter central restrictions on information collection.

Awareness. The Paperwork Reduction definition stimulated interest among politicians in a policy area that had previously been an obscure and routine matter with few partisan implications and no excitement. Although Government Intelligence relied on a package of concepts, symbols, and theories, the symbols of rationality and due process had lost much of their political glamour. Before 1974, few elected officials chose to master the details of information policies or to cultivate the natural constituencies of Government Intelligence. By linking information collection to popular and important themes and symbols of political life, the new definition made paperwork an attractive vehicle for politicians to discuss the value of privacy, the virtues of government restraint, skepticism that bureaucrats know best. Once President Ford began to use paperwork reduction as an example of deregulation in speeches to business audiences, other elected officials became aware of the political possibilities of the issue. Nearly all the candidates in the 1976 presidential election campaigned against 'big government,' and paperwork reduction was an easy way to oppose the excesses of government without offending influential beneficiaries of government programs (Cohen 1976). Such campaigning also widened public awareness of paperwork as a problem, and constituencies for paperwork reduction coalesced.

Mobilization. Definitions of problems arouse concern and attract attention by linking problems to ideologies and values. In turn, ideologies and values stimulate and channel activism within government and active efforts to influence government from outside. The package of ideas in Paperwork Reduction mobilized previously quiescent interests around a set of policy proposals, and effectively silenced previously dominant groups. As a result of the allocation of blame and credit, the spread of awareness, and the use of derogatory language, organized groups outside the federal government 
(notably interests representing small business, public schools, and large business) were energized and eventually empowered to resist the collection of information about their activities by federal agencies. In addition, the Office of Management and Budget and the General Accounting Office - agencies with government-wide jurisdiction - sought and eventually received increased control over the information activities of the cabinet departments and independent agencies. The losers were agency officials. Their credibility in decisions about what information they needed was leached away by the Paperwork Reduction definition. Their participation in information policy was reduced by the assumptions and theories of the new regime.

\section{The powers of definition}

Problem definition plays multiple roles in the policy process. The analytical role in which definition creates an intellectual framework for further action has been especially salient to analysts and scholars. The other two roles - as a weapon of advocacy and consensus and as an outcome of policymaking have been less obvious and less well understood. They are harder to understand. The intellectual and symbolic contributions of problem definition tend to blur into the array of political and institutional forces that also bear on policymaking and policy outcomes (Derthick and Quirk, 1985). But difficult to measure and understand is not the same as unimportant. At the same time that these roles as weapons of advocacy and consensus and as policy outcomes pose challenges to researchers, they pose significant opportunities to policymakers and significant implications for government action.

Another theoretical challenge of this conclusion is specifying criteria for evaluation. What is a good problem definition? Is Paperwork Reduction superior to Government Intelligence? The answer lies in how definitions perform as overture, process, and outcome. As overture, Quade (1975) suggests evaluative criteria such as whether the definition considers the whole problem, whether it implies alternatives that have realistic promise of improved outcomes, whether it permits systematic analysis of alternatives, whether it is clear about the objectives to be achieved, whether it focuses attention on a manageable set of factors, and whether the definition is meaningful to decision makers. As process, quite different evaluative criteria emerge: which actors are mobilized to participate in decision making and which are excluded, which actors are placed on the offensive or defensive, which institutions are legitimized and strengthened and which are not, which groups become more credible and powerful, which decisions are made openly in the legislative arena and which are left to bureaucratic discretion. As outcome, yet another criterion becomes paramount: which political 
values are moved forward and which are moved backward. My personal view is that the Paperwork Reduction definition is analytically superior to Government Intelligence, but that its process and outcome consequences have been damaging to values of expertise, rationality, and trust in government that happen to matter to me. Such a conclusion suggests the difficulties inherent in evaluating problem definition, and the clarity that may be gained by separating the three roles for independent judgment.

The complexity surrounding these roles should not obscure the central point. Problem definition has several kinds of power in the policy process, as overture, weapon, and outcome. Deliberation over problem definition is not merely the first stage of policy making. It may recur at each successive stage. Problem definitions are currents in the stream of political discourse. They can be settled, sometimes for many years, facilitating stability and predictability in politics, policy and program. They are used by policy entrepreneurs to build coalitions, overcoming dissensus and fragmentation. They may be challenged and reexamined, undoing consensus as policy proposals wend their way through decision making and implementation. Moreover, serious attention to a given definition is an outcome of significance, as it legitimates some strands of political argument, mobilizes some participants, and invites people to see public issues differently. In its multiple roles, problem definition constitutes a source of both stability and flexibility in the policy process.

\section{Notes}

1. I am grateful for support from the Sloan Foundation and the A. Alfred Taubman Center for Public Policy and American Institutions at Brown University. An early version of this paper was presented at the Conference on Problem Definition in Public Policy at Brown University. The comments of Thomas Anton, Roger Cobb, Judith Gruber, Donald Kinder, James March, and the anonymous reviewers were very helpful.

2. Problem definition is related to, but different from, agenda setting. Problem definition is concerned with the organization of a set of facts, beliefs, and perceptions - how people think about circumstances. Agenda setting refers to the process by which some problems come to public attention at given times and places. A flashy new definition may facilitate the movement of a problem on to the public agenda. But it may not. Many factors other than problem definition influence the competition of problems for the attention of policymakers. See, for example, Kingdon (1984).

3. Select Committees on Small Business held hearings in 1965-66 and in 1971 to rail against paperwork.

4. Representatives Jack Brooks (D, TX) and Frank Horton (R, NY), the chairman and ranking minority member of the House Government Operations Committee, have been the major players on the House side. In the Senate, Lawton Chiles (D, FL) has been most consistently involved, although a number of other Senators on the Committee on Governmental Affairs (successor to the Committee on Government Operations) have sponsored bills and taken an interest in paperwork. Elmer Staats, then Comptroller General, was heavily involved at many points and served on the Commission on Federal Paperwork. 
5. This does not always work, however. Katzmann (1986) describes a case in which an issue network (dealing with mass transportation for physically handicapped passengers) vacillated between two competing definitions for many years.

6. Of course, many federal programs and policies and many streams of political thetoric may influence people's judgments about the appropriate role of the government in society (Heclo, 1986). Paperwork Reduction is only one.

\section{References}

Bennett, W. Lance, P. D. Harris, J. K. Laskey, A. H. Levitch, and S. E. Monrad (1976) 'Deep and surface images in the construction of political issues,' Quarterly Journal of Speech, April: $109-126$.

Brewer, Garry and Peter deLeon (1983) The Foundations of Policy Analysis. Homewood, IL: Dorsey Press.

Carter, Jimmy (1977) Memorandum for the Heads of Executive Departments and Agencies, February. Reprinted in Statistical Reporter, April: 287-288.

Caudle, Sharon L. (1988), 'Federal information resources management after the Paperwork Reduction Act,' Public Administration Review 48: 790-799.

Cohen, Richard E. (1976) 'Big government' emerges as big issue in '76 election campaign,' National Journal, March 6:298-303.

Commission on Federal Paperwork (1976) 'Bits and pieces of the paperwork problem.' Unpublished memorandum.

Commission on Federal Paperwork (1977a) History of Paperwork Reform Efforts: A Report of the Commission on Federal Paperwork. Washington, DC: U.S. Government Printing Office.

Commission on Federal Paperwork (1977b) Final Summary Report. Washington, D.C.: U.S. Government Printing Office.

Commission on Federal Paperwork (1977c) Information Value/Burden Assessment. Washington: U.S. Government Printing Office.

Committee on Government Operations (1976) U.S. Senate. Subcommittee on Oversight Procedures. Hearings on Paperwork Review and Limitation Act of 1976. May: 131-132.

Committee on Government Operations (1980) U.S. House of Representatives. Hearings on Paperwork Reduction Act of 1980, February 7, 21, 26. Statement of Wayne Granquist, Associate Director for Management and Regulatory Policy, OMB, p. 91.

Derthick, Martha (1979), Policymaking for Social Security. Washington, DC: Brookings.

Derthick, Martha and Quirk, Paul (1985), The Politics of Deregulation. Washington, DC: Brookings.

Dery, David (1984) Problem Definition in Policy Analysis. Lawrence, KS: University of Kansas.

Domestic Council, Executive Office of the President (1975) White House Public Forums on Domestic Policy 1975: Report to the President. Gerald Ford Presidential Library.

Downs, Anthony (1972) 'Up and down with ecology: The issue-attention cycle', The Public Interest, Summer: $38-50$.

Duncan, Joseph W. (1975) 'Seeking reductions in the federal paperwork burden,' Statistical Reporter, July: 2.

Edelman, Murray (1988) Constructing the Political Spectacle. Chicago: University of Chicago Press.

Feldman, Paul (1970) 'Commissions on statistics; Statistics on commissions,' Statistical Reporter. November: 73-79.

Ford, Gerald (1975a) Presidential Greeting for First Meeting of Commission on Federal Paperwork. July 23. Gerald R. Ford Library. 
Ford, Gerald (1975b) Address to National Federation of Independent Business. June 17. Gerald R. Ford Library.

Ford, Gerald (1975c) Address to Annual Convention of U.S. Chamber of Commerce. April 28. Gerald R. Ford Library.

Ford, Gerald (1976a) Statement by the President on Progress Toward Reducing the Number of Federal Reports, July 23. Reprinted in Statistical Reporter, August: 277-278.

Ford, Gerald (1976b) Memorandum to the Heads of Executive Departments and Establishments Regarding Reporting Burden Reduction Program. Reprinted in Statistical Reporter, October: $20-24$.

Ford, Gerald R. (1979) A Time to Heal. New York: Harper \& Row.

Elder, Charles and Roger Cobb (1983) The Political Uses of Symbols. New York: Longman.

Gamson, William A. and Andre Modigliani (1987) 'The changing culture of affirmative action,' in R. Braungart (ed.), Research in Political Sociology, Volume 3. Greenwich, CT: JAI Press.

General Accounting Office (1984) 'The Office of Management and Budget's Actions Show Progress in Implementing the Paperwork Reduction Act of 1980,' IMTEC 84-24, September 7 .

Gusfield, Joseph P. (1981) The Culture of Public Problems: Drinking-Driving and the Symbolic Order. Chicago: University of Chicago Press.

Heclo, Hugh (1978) 'Issue networks and the executive establishment,' in: A. King (ed.), The New American Political System. Washington, DC: American Enterprise Institute.

Heclo, Hugh (1986) 'Reaganism and the Search for a Public Philosophy', in: J Palmer (ed.), Perspectives on the Reagan Years. Washington, DC: Urban Institute Press.

Heymann, Philip B. (1987) The Politics of Public Management. New Haven: Yale University Press.

Hopkins, Thomas D. (1986) 'Social Policy and the Regulatory Process,' Working paper 9, Project on the Federal Social Role, National Conference on Social Welfare.

Huntington, Samuel (1981) American Politics: the Promise of Disharmony. Cambridge: Harvard University Press.

Katzmann, Robert A. (1986) Institutional Disability: The Saga of Transportation Policy for the Disabled. Washington, DC: Brookings.

Kaufman, Herbert (1977) Red Tape. Washington: Brookings.

Kingdon, John (1984) Agendas, Alternatives and Public Policies. Boston: Little, Brown, p. 198.

Lance, Bert (1977) Memorandum to the Heads of Executive Departments and Establishments: Subject President's Reporting Burden Reduction Program, February. Reprinted in Statistical Reporter, April: 288-291.

Light Paul C (1982) The President's Agenda: Domestic Policy Choice from Kennedy to Carter. Baltimore: Johns Hopkins University Press.

Neustadt, Richard M (1981) 'Taming the paperwork tiger,' Regulation, January-February: 2832.

Oaxaca, Fernando (1976) 'President's Reporting Reduction Program' Statistical Reporter, April: $185-188$.

Office of Management and Budget (1976) Circular A-40, Attachment A, revised February 10, p. 5.

Office of Management and Budget (1978) Paperwork and Red Tape: New Perspectives, New Directions. A Report to the President and Congress. June: 28-33.

Office of Management and Budget (1979) Paperwork and Red Tape. A Report to the President and the Congress. September.

Office of Management and Budget (1981) Information Collection Budget for FY 1981. January. Office of Management and Budget (1984) Information Collection Budget for FY 1984. January. Office of Management and Budget (1985) Information Collection Budget for FY 1985. April. 
'Office of Statistical Standards,' (1952) Statistical Reporter, November.

Quade, E. S. (1975) Analysis for Public Decisions. New York: Elsevier.

Sabatier, Paul A. (1988), 'An advocacy coalition framework of policy change and the role of policy-oriented learning therein,' Policy Sciences 21: 129-168.

Senate Report 96-930 (1980) Paperwork Reduction Act of 1980: Report to Accompany S 1411. Committee on Governmental Affairs, Subcommittee on Federal Spending Practices and Open Government. September 8.

Sundquist, James (1976) 'Congress and the president: Enemies or partners?' in H. Owen and C. Schultze (eds.), Setting National Priorities: The Next Ten Years. Washington: Brookings.

Weiss, Janet A. and Judith Gruber (1984) 'Using knowledge for control in fragmented policy arenas,' Journal of Policy Analysis and Management, Winter: 225-247.

White House Press Office (1976) Transcript of Meeting of President Ford and Members of the Regulatory Agencies and Administration Officials. April 8. Gerald R. Ford Library. 